\title{
Grinting Fried Onion: Empowerment of Grinting Youth Enterpreneur based Digital Village
}

\author{
Halim Purnomo1), Tumin²), Friman Mansir³), Dien Noviany Rahmatika ${ }^{4}$ \\ ${ }^{123}$ Universitas Muhammadiyah Yogyakarta, ${ }^{4}$ Universitas Pancasakti Tegal \\ Email: halimpurnomo@umy.ac.id*)
}

\begin{abstract}
The purpose of devotion is to provide knowledge and skills of online marketing to the younger generation by utilizing e-commerce technology to develop youth Small and Medium Enterprises (SMEs) in Grinting Village. The participants consisted of 25 member SMEs of fried onions specifically for the people of Grinting Village. The materials provided include the creation of an online shop account, product uploads, marketing up to the online financial system. This service was carried out in Grinting Village, Bulakamba District, Brebes Regency, Central Java with the target of the community and the younger generation, especially the entire management of Karang Taruna Garuda Jaya Grinting Village. This cooperation is based on the cooperation between Universitas Muhammadiyah Yogyakarta and grinting village government. The method used is to provide training materials through presentations accompanied by e-commerce implementation training. The achievement of this devotion is the implementation of the service activities in accordance with the expected number of participants as many as 25 administrators and members of Karangtaruna Garuda Jaya Grinting Village independently can develop SMEs for economic independence. Participants gain knowledge and skills about e-commerce implementation to capture developing and mentoring SMEs in local villages.
\end{abstract}

Keywords: SMEs, Grinting, empowerment, e-commerce, training

\section{Introduction}

Grinting village is one of the villages located in Bulakamba District, Brebes Regency, Central Java Province. Grinting Village is directly adjacent to the Java Sea in the north and is traversed by the pantura line in the south. Rice fields and beaches close to the Java Sea are used by the community to meet the cost of living. No wonder that many people depend on agricultural products and seafood in the area (Magesa et al., 2015). Agriculture and fishermen are generally one of the livelihoods for grinting people. Most of the people have a home industry namely fried onion which is closely related to the entrepreneurial spirit owned by the local population. This condition directly actually has considerable potential to help overcome the needs of people's lives, especially the economic independence of the youth in Grinting Village. Most of the people have a home industry namely fried onion which is closely related to the entrepreneurial spirit owned 
by the local population. The economy is moving thanks to local efforts in the economy during the covid-19 pandemic (Hossain, 2021). This condition directly actually has considerable potential to help overcome the needs of people's lives, especially the economic independence of the youth in Grinting village. This is also experienced by people in Indonesia who almost all lines struggle to survive in economic conditions (Susilawati et al., 2020).

The existence of the current pandemic makes some people in Grinitng Village suffer serious impacts such as their efforts to reduce income and even have to be willing to reduce workers until a shift is done to reduce the spending mark up (Elistia, Mudijarto, Mahadewi \& Muhmin, 2021) explained that the impact of the covid-19 pandemic is really bad for SMEs, declining sales, many of them whose businesses are stagnant, even close. The other side of online marketing training according to (Pranoto et al., 2019) can encourage teenagers to overcome and develop their business online. Home industry in Grinting Village or often we know with SMEs have marketing cooperation through BUMDes (Village Owned Enterprises). One of the business managers also said that producing on a certain day alone is due to the current viral pandemic. In addition, this business has not been able to compete on social media. However, after attending online marketing and financial management training can encourage the spirit of re-defense and development of SMEs that have been lived. This is in line with existing informal economic conditions to be able to strive in the midst of the covid-19 pandemic (Webb et al., 2020).

Therefore, through the Institute of Research, Publication, and Community Service (LP3M) Universitas Muhammadiyah Yogyakarta, this devotional activity is carried out more focused on it development in SMEs. On this occasion with various hopes in order to help in increasing sales of SMEs products more widely through online marketing (Hakim, 2019) explained that online marketing has been felt, namely the change in public consumption patterns, especially for the consumption of clothing from those who usually shop offline in stores, outlets, supermarkets or malls some consumers turn to online shopping. Using technology in product promotion will be a new way for SMEs to be able to keep moving in the economy (Kawa \& Wałęsiak, 2019)

\section{Method}


The training and development process refers to the development of human resource management developed by (Hakim, 2019) namely: 1) Determining specific needs; 2) Determine specific objectives; 3) Choosing methods and delivery systems; 4) Implementing the program (training); and 5) Evaluate the program (training). (Hakim, 2019) explains the five steps of the training and development process, namely 1) Analysis of needs, namely knowing the specific work skills needed, analyzing the skills and needs of candidates to be trained, and developing measurable special knowledge and achievement objectives; 2) Plan instructions, to decide, compile, and produce the contents of training programs, including workbooks, exercises, and activities; 3) Validation, in which the people involved create a training program by presenting it to several initiators who can represent; 4) Implementing the program (training) that is training targeted employees; 5) Evaluation and follow-up, in which management assesses the success or failure of the program run.

\section{Result and Discussion}

\subsection{Result}

This community service activity carries the theme of empowering digital-based SMEs. As a result of the pandemic, all systems must be based online in line with the demands and challenges faced, not least in the mentoring program for the development of fried onion SMEs in Grinting Village in order to remain able to adapt to various changes in the conditions of this pandemic (PURWANINGDYAH et al., 2020) explained that online marketing during the pandemic is the right way to develop SMEs. Some of the training provided include:

\subsection{Discussions}

\section{Social Media Socialization}

The introduction of social media to partners became one of these programs because previous partners had not all been able to utilize social media as a market place for the development of fried onion SMEs. Through the socialization, partners can use social media in their business. (Agatha Rinta Suhardi, Vina Silviani Marinda, Titto Rohendra, Ivan Gumilar Sambas Putra, 2020) explained that online marketing encourages the growth of new entrepreneurs. The introduction of social media was 
carried out in seminar programs and discussion forums with the materials presented. Not only that, the social organization Karang Taruna also participated in this socialization. Socialization delivered in the form of how to create materials or content for social media, how to create interesting captions, how to upload the material, etc. With this socialization, it is expected that partners can compete and not lose to other SMEs.

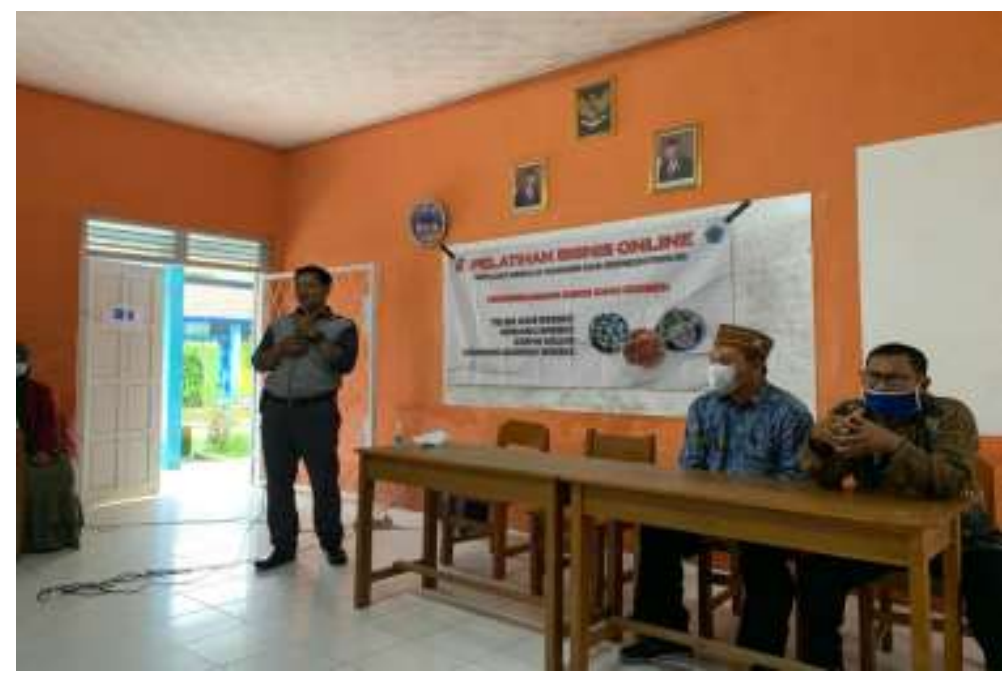

Figure 1. Implementation of socialization as well as online marketing training SMEs

Fried Onionin in Grinting Village Bulakamba District Brebes Regency Central Java.

\section{Product Photos}

Interesting product photos are also indispensable. The raw material of fried onions is produced directly from the onion farmers of Grinitng Village. Furthermore, being managed by SMEs becomes an attractive look. Because so far the appearance of fried onion products has not been interesting, apalgi has aesthetic value. This becomes a demand for SMEs to be able to display their products to attract prospective buyers both offline and online. Therefore, the first program implemented is training to upload photos of fried onion products throughout social media as a market place.

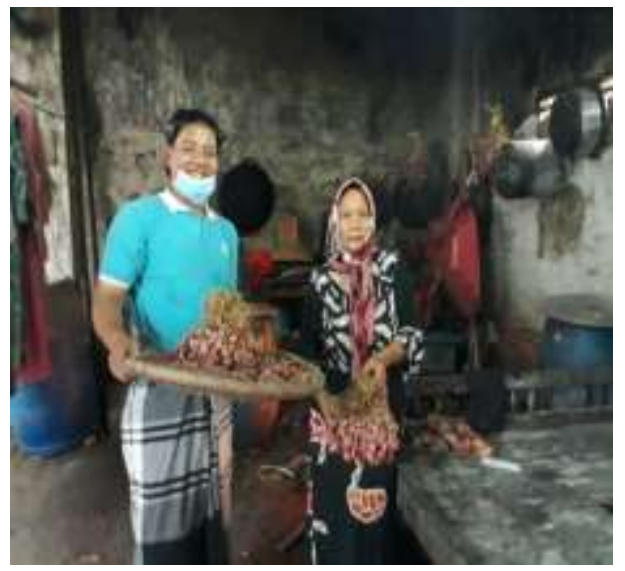

119 | Licensed under Creative Commons Attribution-NonCommercial 4.0 International License ISSN:2798-8252 (Online) 
Figure 2. Raw materials fried onions directly from farmers in the local village

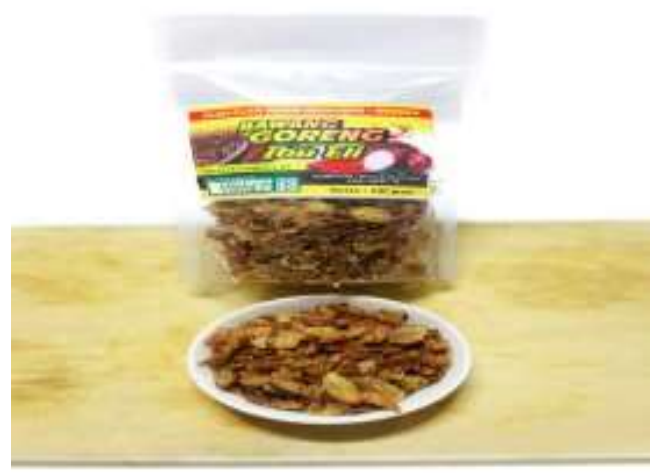

Figure 3. Interesting view of fried onions before being uploaded on social media.

\section{Create an Online Shop Account}

Nowadays social media accounts are very instrumental in introducing products to a wide audience. Not only that, social media can also be used as a marketing tool that can quickly reach the desired target of SMEs. Grinting Village SMEs has not used all social media to conduct product introduction and marketing. So this devotion decided to assist the creation of Instagram, WhatsApp Business and Facebook accounts. The creation of social media accounts is expected to be useful for SMEs partners. Initially starting from the division of groups for each social media, then the group will create their own social media accounts and think about the content of the social media accounts.

An example of what's been done is creating an Instagram feed using the same theme and other interesting things. This Instagram contains the name of what products are sold, the price of each product, and others. While another example is a Youtube account that contains the process of making products, and others. Creating a social media account can help drive sales of partner products by using reach marketing that is on Instagram social media. This will greatly help the expansion of the product so that it is known out of town and can drive sales at the time of the covid pandemic. 


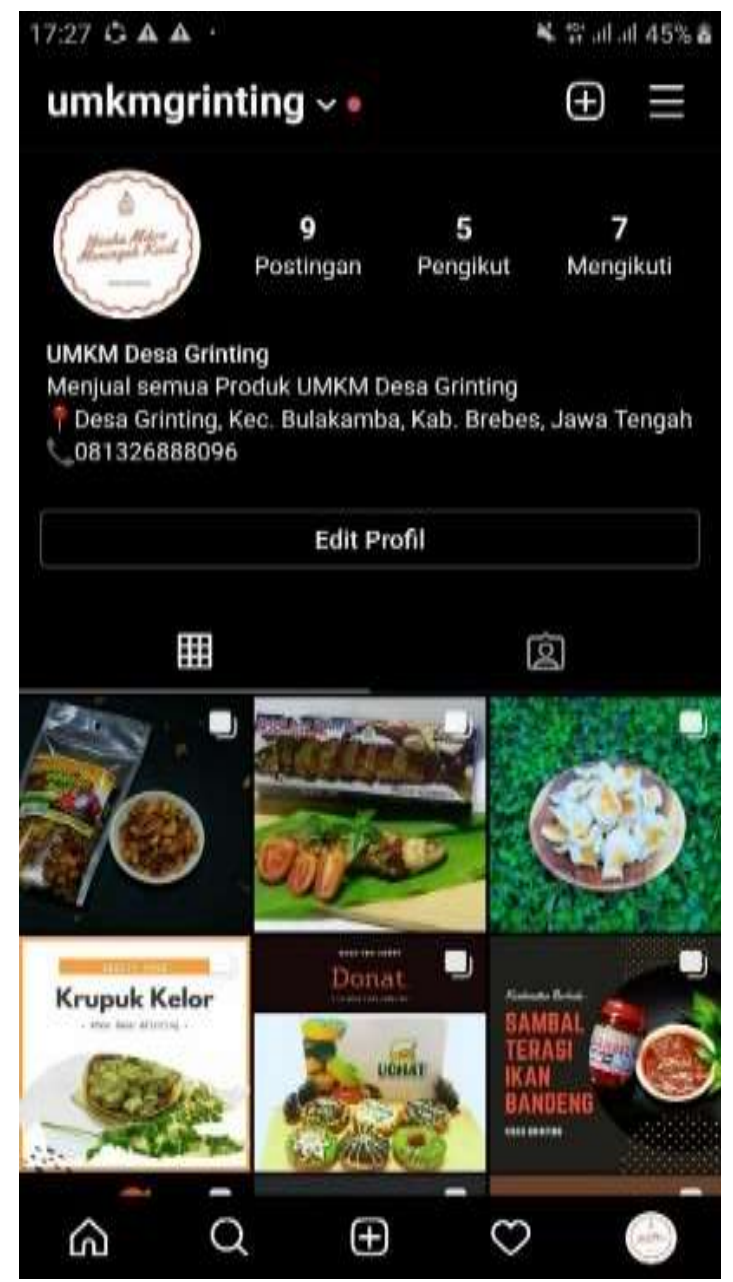

Figure 4. Display of Grinting Village SMEs account on social media https://www.instagram.com/p/CLF2Gh1lE63/?igshid=yz9g810z8ry1 


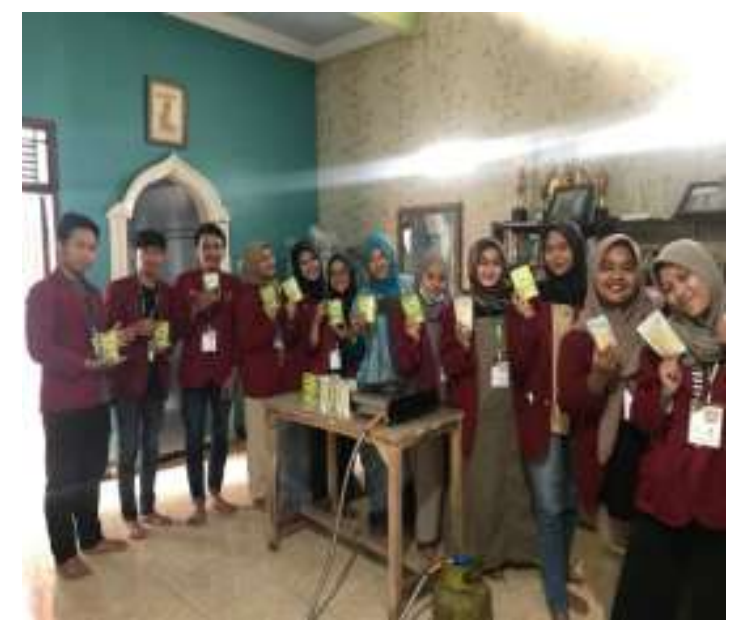

Figure 5. Ongoing training mentoring

\section{Devotional Work: Additional devotion}

Furthermore, in addition to online marketing training, there is also an additional program of community service activities, namely the work of major road repair services in Grinting Village as an effort to drive the smooth mobilization of the economy in the local village through representative road infrastructure. In the end the hollow road was flooded with water. Therefore, the need for road repairs by adding gravel stones to the hole, hopefully this can add to the comfort of the people of Grinting Village.

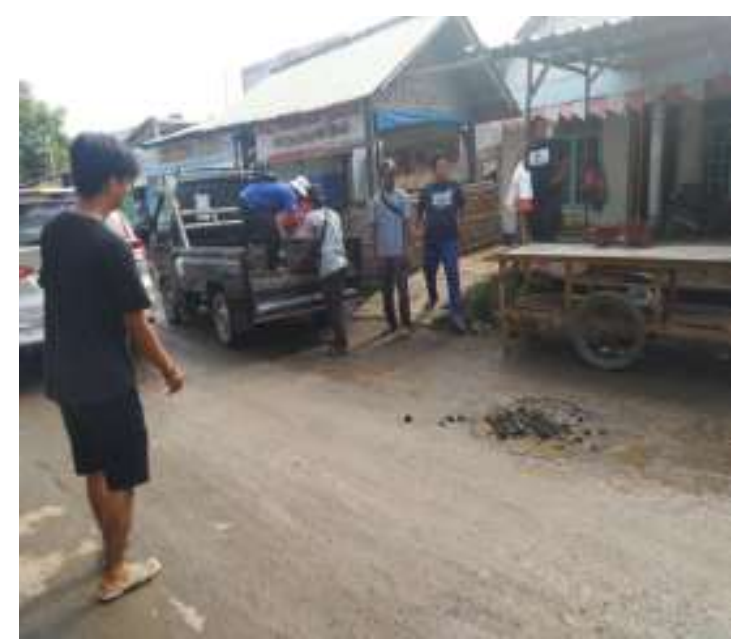

Figure 6. Road improvement program as an additional program of community service

\section{Conclusion}

Training and mentoring online marketing through social media or digital marketing provided to partners can market their products more widely so that the reach of marketing products is easier to obtain by consumers without being limited by space and time. Furthermore, the additional program in this service is the work of improving the 
main road facilities of Grinting Village in order to smooth the mobilization of the community economy.

\section{Reference}

Agatha Rinta Suhardi, Vina Silviani Marinda, Titto Rohendra, Ivan Gumilar Sambas Putra, A. B. (2020). PPelatihan Digital Marketing Pada UMKM Binaan KADIN Jawa Barat Dalam Menghadapi Era New Normal. Journal of Chemical Information and Modeling, 53(9), 1689-1699.

Elistia, Mudijarto, Mahadewi, E. P., \& Muhmin, A. H. (2021). Pelatihan Pengelolaan Manajemen Bisnis Untuk UMKM di Era New Normal. The 2nd Seminar Nasional ADPI Mengabdi Untuk Negeri Pengabdian Masyarakat Di Era New Normal Prosiding Vol 2. No 2 (2021), 2(2), 295-298.

Hakim, L. (2019). Pelatihan Pemasaran Online Berbasis Marketplace Bagi UMKM Dalam Merespon Perubahan Perilaku Konsumen. Loyalitas, Jurnal Pengabdian Kepada Masyarakat, II(1), 74-91.

Hossain, M. (2021). The effect of the Covid-19 on sharing economy activities. Journal of Cleaner Production, 280. https://doi.org/10.1016/j.jclepro.2020.124782

Kawa, A., \& Wałęsiak, M. (2019). Marketplace as a key actor in e-commerce value networks. Logforum, 15(4). https://doi.org/10.17270/J.LOG.2019.351

Magesa, M. M., Michael, K., \& Ko, J. (2015). Towards a framework for accessing agricultural market information. Electronic Journal of Information Systems in Developing Countries, 66(1). https://doi.org/10.1002/j.1681-4835.2015.tb00473.x

Pranoto, P., Jasmani, J., \& Marayasa, I. N. (2019). Pelatihan Digital Marketing Untuk Peningkatan Perekonomian Anggota Karang Taruna Al Barkah Di Kampung Cicayur - Tangerang. Jurnal Pengabdian Dharma Laksana, 1(2), 250. https://doi.org/10.32493/j.pdl.v1i2.2425

PURWANINGDYAH, S. W. S., SUMADHINATA, Y. E., \& KUSWARA, G. B. (2020). Pentingnya Pelatihan Peningkatan Pengetahuan Marketing Online Di Era Pandemi Covid 19 Bagi UMKM Di Wilayah Jawa Barat. Prosiding Konferensi Nasional Pengabdian Kepada Masyarakat Dan Corporate Social Responsibility (PKM-CSR), 3, 1140-1143. https://doi.org/10.37695/pkmcsr.v3i0.951

Susilawati, S., Falefi, R., \& Purwoko, A. (2020). Impact of COVID-19's Pandemic on the Economy of Indonesia. Budapest International Research and Critics Institute (BIRCIJournal): Humanities and Social Sciences, 3(2). https://doi.org/10.33258/birci.v3i2.954

Webb, A., McQuaid, R., \& Rand, S. (2020). Employment in the informal economy: implications of the COVID-19 pandemic. International Journal of Sociology and Social Policy, 40(9-10). https://doi.org/10.1108/IJSSP-08-2020-0371 